\title{
An Empirical Study in Human Resource Management to Optimize Malaysian School Counselling Department
}

\author{
Gholamreza Zandi ${ }^{1}$, Ananda Devan Sivalingam ${ }^{1} \&$ Shaheen Mansori ${ }^{2}$ \\ ${ }^{1}$ Universiti Kuala Lumpur Business School, Malaysia \\ ${ }^{2}$ Malaysian University of Science and Technology (MUST), Malaysia \\ Corespondence: Ananda Devan Sivalingam, Universiti Kuala Lumpur Business School, Malaysia.
}

Received: April 30, 2019

doi:10.5430/ijfr.v10n5p32
Accepted: May 30, 2019

Online Published: June 10, 2019

URL: https://doi.org/10.5430/ijfr.v10n5p32

\begin{abstract}
This conceptual paper is to study the departmental improvement that needs to be implemented at Malaysian Schools Counselling Center by integrating Human Resources Management Practices. The study reviews literature on the Historical Background of Malaysian School Counselling Center and human resource management practices. The paper goes on to analyse factors and perceptions that is needed for revamping a systematic Counselling and Career Development Center in schools. Furthermore, its operational needs relevant human resource management approach which will contribute towards building the future human capital via the school systems. As human capital is the backbone of any country, it has become essential for any nation to produce the right human capital to ensure the workforce of the country is able to develop well balance country from political, economic and socially. However, there is rising challenges for the education sector to produce and feed the talents and various initiatives have been addressed in the Malaysian Education Blueprint 2013- 2025(MEB) by the Ministry of Education Malaysia. Hence, pilot study will be carried out at two governments secondary school in Malaysia located in an urban and a sub urban platform and to contribute at end of the research towards improvement in schools counselling center by using Human Resource Management approach. It is also aim that can support future studies can be carried out based on the practical implementation.
\end{abstract}

Keywords: HRM, school counseling, leadership, training, communication, motivation

JEL Classification: A20, I25, I29, J24

\section{Introduction}

Human capital is the backbone of any country and in today's globalization environment; employees play a central role in the success of any organisation. In the constant competitive business environment, it has become essential for any nation to produce the right talent to ensure the workforce of the country is able to develop a well balance country from political, economic and socially and schools has greater responsibility in leading and managing based on the constant changes.

The Malaysian Education Systems have been an attention of research because educational performance is the key for producing talent and economic growth. This is particularly when the education system is operated as an engine for preparing students for employment or as a job creator. For Malaysia to move forward in this never ending Digital Economy, Industry 4.0 and Globalization era, having the right talent and skills is essentials. Moreover, having the abilities to adapt new knowledge is crucial.

Therefore, for Malaysia to continue to progress in developing human capital, basic fundamental as to be right. Schools have to be prepared to welcome the changes the economy and industries demands for. Hence, this research has been focused towards bridging the gap by addressing how a departmental improvement can be achieved in Malaysian schools counselling center by using Human Resource Management (HRM) Philosophy. Hence, this study is aim to be carried out at (2) government secondary school in Malaysia one located in an urban platform and secondly at a sub urban platform. 


\subsection{Problem Statement}

The counselling unit at Malaysian schools may be heading for difficult times with the constant challenges the schools administration is facing with the stigmatization and human resource management challenges. It is almost 56 years since 1963 the existence of counselling and guidance services in Malaysian schools and there is still work needs to be carried out before an effective and comprehensive center can be successfully implemented.

Various researcher have pointed out that issues such as time constraint due to various job functions, lack of cooperation from administrators, teacher and parents, lack of competent counselling skills, lack of state of art facilities and limited funding adds on the challenges to the department daily operations in addition to various unethical activities are on the rise such as school bully, drugs, gangsterism, prostitution and also recruitment as an agent for terrorism. Moreover, challenges in academic in literacy and numeracy, softs and technical skills in ensuring the future talents are equipped as the nation's workforce is also questionable. To make situations more challenging, the Malaysia Crime Prevention Foundation (MCPF) 2018 reported that about 4.2 Million Malaysian youth age 16 and above are suffering from mental problems which is leading to delinquency or crime in the country.

The researcher discovered that there are various publications related to bringing the changes needed towards the counselling centers however, there was no confirmation that the effort to implement the concept or study in schools was achieved. Therefore, the researcher believes that one way to enhance the centers is to carry out a study by practically piloting the implementation to achieve the targeted results by increasing the Human Resource Management functions and concepts focusing on literatures that addressed on learning and development, leadership building, motivation and communication. This direction was communicated with the Ministry of Education Malaysia (MOE) in early 2014 by the researcher towards finding ways to optimize the Malaysian school counselling center using human resource management approach as a pilot study and suggested ways to de-stigmatize the counselling unit and to pilot the new concept or name towards the counselling centers.

MOE welcomed the suggestion under the education Malaysian Education Blueprint 203-2025 (MEB) Shift 9 platforms. However, MOE can only provide support in terms of approvals and not financially due to limited budget. If the researcher is still keen to carry out the concept, it has to be self-funded. Furthermore, a practical implementation of any concepts needs a tangible entity officially working with the MOE. Amir \& Latiff (1984) did point out that due to lack of funding and human resources, the guidance plans did not take off as planned in past at Malaysian schools and after various efforts it revived in a later stage when the funding was available. Yet, based on initial discussion with school leadership and teachers, the counselling center still faces various challenges that have been pointed by various researchers. The researcher anticipates that this challenges will not be able to tackle any time soon if there was no a practical implementation of the findings by all the researchers.

To summarize in the past, 1) many researcher maybe subjected to limited funding towards implementing their research studies. 2) Stakeholder support towards this direction might be limited towards implementing their research studies. 3) There is a need of a lengthy compliance and polices to be addressed with MOE towards implementing their research studies. However, the introduction of Malaysian Education Blueprint 201-2025(MEB) Shift 9 platforms may be a solution that allows any stakeholders to support in any means of contribution that they are able to. Therefore, the researcher pursued to carry out the study by integrating human resource management functions and philosophy hoping to optimize the counselling center by this study (Okon \& Zhizhi 2016; Eze, 2018).

\subsection{Purpose of Inquiry and Inquiry Questions}

This conceptual paper objective is intended to identify, understand, and analyse the data regarding human resource management philosophy and issues in counselling center at Malaysian schools based on the literatures and implement practically the suggested model to MOE. Therefore, the inquiry questions for this paper are:

1. Is there a lack of understanding between human resource management philosophies in schools among teachers and administrators?

2. What current human resource practices are regarded as most successful and least successful in human resources in schools towards counselling department?

3. Is there a stigmatization among school leadership, teachers, parents and students regards to counselling departments and are they open for change to implement practically? 


\section{Theoritical Framework}

This conceptual framework was design based on the input from literature and interviews from two school leadership and stakeholders. Therefore, the researchers have focused on the conceptualization by focus on leadership building, training and development, motivations and communication.

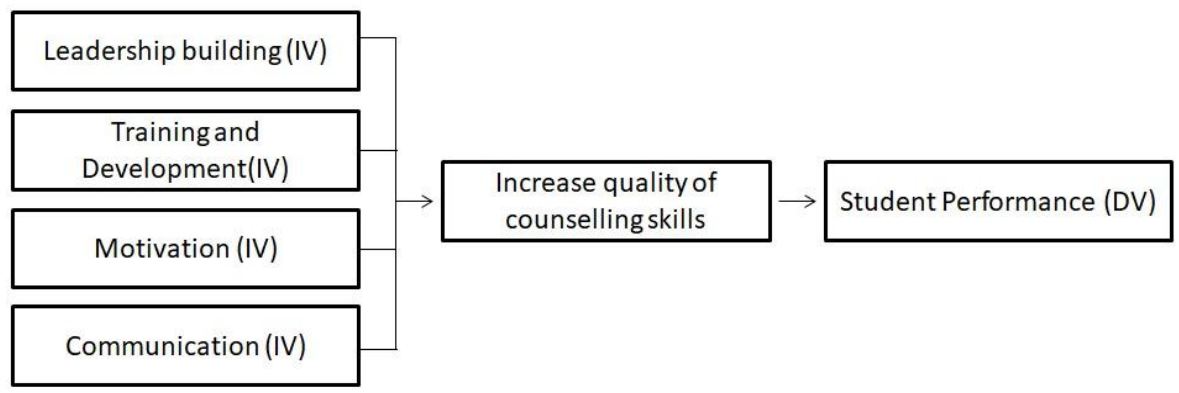

Figure 1. Suggested conceptual framework for this study by researchers

\section{Review of the Literature}

The Literature was divided to two areas focusing on the approach related to HRM and School Counselling.

\subsection{Challenges in National Government School With Counselling Center}

Schmidt (2008) stated that counselling and guidance programme should be able to address the career and personal development and social development of the students. However, Chai (2000) argued that, only $16.6 \%$ of students actually utilised the counselling services for emotional or mental problem due to unwillingness to reveal their difficulties to another person. It was spell out that student will only seek counsellor assistance when their primary support system has failed to effectively solve their problem. Gysbers \& Henderson (2001), a western researcher also argued that a school comprehensive counselling programme should take note of supporting the pupils and include all the stake holders of education. This statement was in line with the work done by Parham \& Tinsley (1986) nearly 3 decades ago.

In Malaysian schools, generally a counselling center is always seen as a place for problematic students. Those who are extremely naughty, stubborn, lazy and love to break the rules and regulations in the scope of disciplinary, ethics, academic and even having personal issues will be scheduled to sit with the school counsellor regardless whether it is their favour or not. In fact, counselling itself is containing limited definitions as consultation, advising, and guidance which lead to doubt by many people in general. Indeed, most parents and students will express likelihood of thinking and feeling negative when it comes to counselling matters argued Jin \& Sew (2012); Elad, Ngan \& Bongbee (2017); Eketu, (2018). The stigmatization on the counselling unit is a major issue that need to be highlighted and there is a need for a new shift or name. This stigmatization and lack of understanding about what counselling is all about in the secondary school culture have gradually increased the challenges for educator, counsellors and school leadership.

Similarly, the researcher pointed out the statement by Jarvis\& Keeley (2003) that the school counsellors should provide career development interventions in a new paradigm and not only focusing on a counselling aspect alone. These views have also been argued by Tan (1989), 28 years ago that counselling was not popular in secondary schools due to the stigmatization. Furthermore, Aminah (1988) and Zulkifli (1986) pointed out that there have not been many changes over the years in this stigmatization and the counselling services in secondary schools are still being labelled for problematic students by students, parents and school staff. It is alarming that there was not much change towards the counselling center after Jin \& Sew (2012) studies. That is 6 years ago and nearly 3 decades since the studies by Zulkifli (1986), Aminah (1988) Tan (1989) and Dong \& Lin (2017).

\subsection{HRM Approach Towards National Government School Counselling Center}

The counselling services in school do not receive adequate provision in terms of understanding the human resource operational view of the department from the school administration or leadership. Santrock (2001) stated that as a learning institution, school managers especially where leadership and governance is concerned needs to be integrated with various departments if the HRM is comprehended. Furthermore, the leadership of a learning organization are responsible in establishing the right framework to face the challenges and adapting to the changes. According to Mukhtar \& Muslizah (2004), the "head of the school" is the key factor in how effective the school and the 
department functions. In an effective school, the "principal" acts as an instructional leader and effectively communicates the school's mission to the staff, parents, and students. The principal should understands and apply effective leadership skills to enable both students and staff to achieve the desired school and student achievements (Ahmed, Isa, Majid, Zin \& Amin, 2017; Okon, 2018).

As what Ulrich (2007) stated, good human resource practices for some organisations creates demonstrable value for an organisation's key stakeholders and prove that human resources is worthy of a seat at the executive table. If the leadership is clear, any new changes can be implemented for the benefit of the beneficiary.

\subsubsection{Leadership}

Gladding (1997), stated that school counsellor leadership seemed especially relevant in public education and the increased emphasis on academic achievement. As a concept, leadership is difficult to define. The large number of proposed leadership models and the vast literature base on leadership topics indicates a history of researchers and professionals attempting to define leadership.

According to Northouse (2004), who stated that leadership is a process whereby an individual influences a group of individuals to achieve a common goal. As for this study, the school leadership and administration, teacher should clearly understand that leadership is vital in order to bring the changes towards counselling center in Malaysian school. The literature on leadership demonstrates that various disciplines and fields such as sociology, psychology, business, management, and organizational theory have contributed to models of leadership practices and leadership structures (Bush, 2003; Katzenmeyer \& Moller, 2001; Northouse, 2004; Dar \& Bhat 2018).

According to (Bennis, 1994; Northouse, 2004; De, 2018), currently, the most popular theory of leadership and one that seems to mesh well with recent reforms in school counselling is that of transformational leadership. Transformational leaders are recognized as change agents who are good role models, who can create and articulate a clear vision for an organization, who empower followers to achieve a higher standard, who act in ways that make others want to trust them, and who give meaning to organizational life explains Northouse (2004).

\subsubsection{Training and Development}

Megginson, Matthews \& Banfield (1993) has defined training as a relatively systematic attempt to transfer knowledge or skills from one who knows or can do to one who does not know or cannot do and education is conventionally seen as a highly structured exposure to planned learning, the objective of which is to train the mind. According to Daud (1986), training has often been associated with education and in many instances the term training and education program are used interchangeably. In the context of quality, training and education program is to provide the necessary skills, knowledge and the abilities to make quality happen and also in the quality improvement environment, everyone is required to gain additional capabilities and competencies to improve the process (Haseeb, Abidin, Hye \& Hartani, 2018).

Therefore, a comprehensive training and education program is necessary and must be institutionalized within the entire organization (Saylor, 1999; De, et.al., 2018). Once the management has the skills to lead the quality improvement process, the rest of the organization should be trained and educated to ensure a systematic, integrated and consistent organization-wide. Thus, training and development are considered as a failure if they do not result in a change in behaviour of the employees and most organizations already realize now that training and development program is an integral and essential part of the quality improvement initiative claimed (Juran and Gryna, 1993; Dierker, et.al., 2018).

Thurow, (1996) stated that, In an era of globalization and global free trade where geographic walls in terms of technology transfer are easily overcome, competitive success of the organization largely depends on the talent and ability of the people rather than latest available technologies and therefore training and development of workers is considered highly important because knowledge-workers are important to any organization

\subsubsection{Motivation}

Motivation generally can be categorised as intrinsic and extrinsic motivation. Intrinsic can be defined as individuals are motivated to execute or do things because they simply enjoy doing them without and influence on their decision. On the other hand, extrinsic motivation defines as individual do things because they get something by doing it. Example: reward, praise, promotion or fear of consequences for not executing a task or things that are expected from that individual (Jermsittiparsert et al., 2016; Okpechi, et.al., 2018).

According to Brooks (2001), motivation is defined as the forces that compel action and direct the behavior of individuals. Furthermore, Simpson (2001) states that a critical function of school counselors and school counseling 
programs is to help students and counselors to understand their personal motivators and to learn how to improve their motivation in order to achieve at their highest potential in their job, school and in life. As for schools, it is vital that this aspect is highlighted further on this study

\subsubsection{Communication}

According to Mohan, McGreir, Saunders \& Archee (1997), an effective counsellor does require to be effective communicator with the relevant communication skills to help them achieve the quality of delivering. They will require having an understanding of self and a detailed awareness of the impact of oneself on others, advanced listening skills, levels of empathy, an open mind ability, negotiation and problem solving, ability to read, interpret and respond non-verbally is critical and use the ability to model his or her behaviour for the client stated Clarkhuff (1969). Batesn (1998) stated that communication HRM mainly related to the effective management of very good communication skills in a one to one situation. If an individual is able to understand their organisation and also the workforce they are dealing with, it will help them to communicate more efficiently by using the right skills when needed.

\section{Research Methodology}

In this study, the researcher has carried out interviews with approval from MOE in two schools in Malaysia located in an urban and sub urban platform targeting school leadership, senior administration and including counsellors with the concepts of focus in leadership building, training and development, motivations and communication. The outcomes of the interviews have led to practically implement the concepts of HRM( Dincer \& Kilinç 2018).

The researcher managed to raise funds from a social enterprise company in Malaysia since 2014- 2018 (SASTRA Education Development/www.sastraeducation.com) by piloting towards repositioning the counselling center with programs and upgrading the infrastructure as Human and Career Development Center that collectively engaged volunteering experts from various field of research, education, business, legal and financial to support in optimizing the Malaysian schools counselling center by integrating the human resource management approach. Moreover, sustainable revenues stream was created to support towards the lack of funding which was addressed by the previous researchers.

These methods have created the possibility that future studies can be further developed by exploring other factors that might be significant to optimize the counselling department. As this was a concept that needed to be validated, this paper sets the scene for future researchers to carried out more studies if needed practically by working with the MEB 2013- 2025.

\section{Conclusion and Recommedation}

Documented research has indicated at present there is an improvement can be made in Malaysian schools counselling center by integrating the Human and Resource Management Philosophy in the areas related to learning and development, leadership building, motivation and communication. Furthermore, based on current findings, various methods can be implemented towards building Malaysian human capital if the limitation can be mitigated or removed. It is possible today that via the school system, the future work force that Malaysia needs can be improved with the support Education Blueprint 2013- 2025. At this juncture, the researcher strongly recommends that the higher education institutions who are training the future graduates in the field of education can integrate the HRM philosophy in their teaching materials and support in addressing the misconception of counselling centers or careers related to it. As Chai (2000) stated, the collaboration between all the stakeholders including the parents, school administrator, and even local community in providing an encouraging school climate will further enhance the human capital of any nation. Therefore, the researcher foresees that this conceptual paper can be further developed to address the issues by various literature and researcher. As Sugrue (2004) states that "making the case for investment in learning has become easier with the growing acknowledgment that human resources is the key to economic and organizational success".

\section{References}

Ahmed, U., Isa, N. M., Majid, A. H. A., Zin, M. L. M., \& Amin, B. M. (2017). Towards understanding work engagement: can HR really buffer HR? Test of a moderated model. International Journal of Economic Research, 14(20), 1-18.

Amir, A., \& Latiff, M. (1984). Guidance and counseling in Malaysian schools: A review and critique. In Third Asian workshop on child and adolescent development (Vol. 2, pp. 1-18). Kuala Lumpur, Malaysia: Universiti Malaysia, Faculty of Education. 
Arulmani, D. (2005). Career psychology and career counselling: core concepts for a work and education curriculum.

Bailey, K. D. (2007). Methods of Social Research (5th ed.). New York: The Free Press.

Bangi Lee, C. S. (2004). Economic growth and employment generation: employers' perspective. Paper presented at the Workshop on Enhancing Graduate Employability in a Globalised Economy, Putrajaya, Malaysia.

Bates, M., \& Stevenson, P. (1998). Good Counselling is Just Excellent Communication Skills! Or is it? Counselling Association of Australia Inc. Journal.

Bennis, W. G. (1994). On becoming a leader. Cambridge, MA: Perseus Publishing.

Brennan, R., Felekis, G., \& Goldring, D. (2003). Strategic management of marketing and human resources in further education colleges. Journal of Further and Higher Education, 27(2), 143-156. https://doi.org/10.1080/0309877032000065163

Brooks, D. B. (2001). Contingency management as a means of reducing school truancy. Education, 95(3), 206-211.

Bush, T. (2003). Theories of educational leadership and management (3rd. ed.).

Chai, M. S. (2000). Fears of psychological treatment and attitudes toward seeking professional help among students. Unpublished Masters Thesis, University Putra Malaysia.

Chai, M. S. (2000). Fears of psychological treatment and Attitudes toward seeking professional help among students. Unpublished Master's Thesis, University Putra Malaysia.

Chang, M. (2004, July 26). Why some graduates are more marketable then others. Paper presented at the Workshop on Enhancing Graduate Employability in a Globalised Economy, Putrajaya, Malaysia.

Creswell, J. W. (2013). Qualitative inquiry \& research design: Choosing among five approaches (3rd ed.). Thousand Oaks, CA: Sage.

Dahir, C. A., \& Stone, C. B. (2003). Accountability: A.M.E.A.S.U.R.E. of the impact school counselors have on student achievement. Professional School Counseling, 6(3), 214-220.

Dar, K. H., \& Bhat, T. A. (2018). Health Sector Efficiency Across Indian States Using Stochastic Frontier Analysis. Asian Development Policy Review, 6(1), 15-19. https://doi.org/10.18488/journal.107.2018.61.15.19

Daud, A. S. (1986). Professionalizing characteristics of the training profession in West Malaysia. Unpublished Doctoral Dissertation, University of Maryland, College Park, USA.

De, A. (2018). Momentum Effect, Value Effect, Risk Premium and Predictability of Stock Returns-A Study on Indian Market. Asian Economic and Financial Review, 8(5), 669-681. https://doi.org/10.18488/journal.aefr.2018.85.669.681

De, A. C., Kurian, S., Dinithi, M. K., Hareesh, N., \& Saira, P. (2018). Social Media For Higher Education: A Cross Sectional Study Among Teachers In India And Sri Lanka. Humanities and Social Sciences Letters, 6(4), 180-188. https://doi.org/10.18488/journal.73.2018.64.180.188

Dierker, L., Evia, J. R., Singer-Freeman, K., Woods, K., Zupkus, J., Arnholt, A., ... \& Rose, J. (2018). Project-Based Learning in Introductory Statistics: Comparing Course Experiences and Predicting Positive Outcomes for Students from Diverse Educational Settings. International Journal of Educational Technology and Learning, 3(2), 52-64. https://doi.org/10.20448/2003.32.52.64

Dincer, N., \& Kilinç, Z. (2018). The Analysis of Stress Levels of the Female Wrestlers Studying in Higher Education (A Case of Batman Province). Asian Journal of Education and Training, 4(3), 156-160. https://doi.org/10.20448/journal.522.2018.43.156.160

Dong, T., \& Lin, X. (2017). Strategies on English Synonym Teaching in Senior High School in the Light of Social Constructivism. International Journal of English Language and Literature Studies, 6(3), 63-68. https://doi.org/10.18488/journal.23.2017.63.63.68

Eketu, C. A. (2018). Perspectives on Human Nature and Implications for Research in the Behavioural Sciences. International Journal of Emerging Trends in Social Sciences, 4(1), 42-46. https://doi.org/10.20448/2001.41.42.46

Elad, F., Ngan, W., \& Bongbee, N. (2017). The Role of board characteristics in effective corporate governance: The case of Airbus Group. https://doi.org/10.2139/ssrn.2902928 
Erford, B. T., House, R., \& Martin, P. (2003). Transforming the school counseling profession. In B. T. Erford (Ed.), Transforming the School Counseling Profession. Columbus, OH: Merrill/Prentice Hall.

Eze, P. (2018). An Analytical Model of Demand for Hospital Inpatient Care. International Journal of Social Sciences Perspectives, 2(1), 80-86. https://doi.org/10.33094/7.2017.2018.21.80.86

Farndale, E., \& Paauwe, J. (2004). Best practice template for global HR. European Business Forum, 19, 72.

Ferris, G. R., Hochwarter, W. H., Buckley, M. R., Harrell-Cook, G., \& Frink, D. D. (1999). Human resources management: Some new direction. Journal of Management, 25(3), 385-415. https://doi.org/10.1177/014920639902500306

Gladding, S. T. (1997). Community and agency counseling. Upper Saddle River, NJ: Merrill.

Glamcevski, M. (2008). The Malaysian counselling profession: History and brief discussion of the future. Counselling, Psychotherapy, and Health, 4, 1-18.

Gysbers, N. C., \& Henderson, P. (2001, April). Comprehensive guidance and counseling programmes: A rich history and a bright future. Professional School Counselling, 4(4), 246-256.

Harris-Bowlsbey, J. (2003). A rich past and a future vision. The Career Development Quarterly, 52, 18-25. https://doi.org/10.1002/j.2161-0045.2003.tb00623.x

Haseeb, M., Abidin, I. S. Z., Hye, Q. M. A., \& Hartani, N. H. (2018). The Impact of Renewable Energy on Economic Well-Being of Malaysia: Fresh Evidence from Auto Regressive Distributed Lag Bound Testing Approach. International Journal of Energy Economics and Policy, 9(1), 269-275.

Hashim, A. (1988). Masalah yang dihadapi oleh murid Tingkatan 4 di Sekolah Menengah dan orang yang ditemui untuk mendaptkan pertolongan. Unpublished Masters Thesis, University Putra Malaysia.

Hines, P. L., \& Fields, T. H. (2004). School counseling and academic achievement.

Huang, W. S., \& Shen S. P. (2012). A study of the relationship among work values, and teaching efficacy of junior high school teachers in Kaohsiung City. Curriculum \& Instruction Quarterly, 15(4), 161-188.

Jarvis, P. S., \& Keely, E. S. (2003). From vocational decision making to career building: blueprint, real games, and school counselling. The Professional School Counselling, 64(4), 244-250.

Jermsittiparsert, K., Sriyakul, T., Pamornmast, C., Rodboonsong, S., Boonprong, W., Sangperm, N., ... \& Maneechote, K. (2016). A Comparative Study of the Administration of Primary Education between the Provincial Administration Organisation and the Office of the Basic Education Commission in Thailand. The Social Sciences, 11(21), 5104-5110.

Jones, J. J., \& Walters, D. L. (1994). Human resource management in education. Lancaster, PA: Technomic Publishing.

Juran, J. M., \& Gryna, F. M. (1993). Quality planning and analysis (3rd ed.). New York:Prentice-Hall. McGraw-Hill.

Katzenmeyer, M., \& Moller, G. (2001). Awakening the sleeping giant. Thousand Oaks, CA: Corwin Press.

Khalim, Z. (2014). Pengurusan disiplin pelajar sekolah. Universiti Kebangsaan Malaysia.

Kok, J. K., Low, S. K., Lee, M. N., \& Cheah, P. K. (2012). 2nd International Conference on Social Science and Humanity. IPEDR, 31.

Lin, C. Y., Ho, Y. T., Hsieh, Y. H., \& Hsu, H. Y. (2010). The causal relationship between job characteristics and preschool teachers' job involvement: The meditational role of organizational commitment. Formosan Education and Society, 20, 105-143.

Lloyd, A. P. (1987). Counselor education in Malaysia. Counselor Education and Supervision, 26, 221-227. https://doi.org/10.1002/j.1556-6978.1987.tb00721.x

Malaysia, D. S. S. (1994). Perkhidmatan bimbingan dan kaunseling: Kajian keperluan, pelaksanaan dan prospek. Selangor: Pustaka Akademik.

Megginson, D., Matthews, J. J., \& Banfield, P. (1993). Human Resource Development. London: Kogan Page.

Mohan, T., McGregor, H., Saunders, S., \& Archee, R. (1997). Communicating!: theory and practice (4th ed.). Sydney: Harcourt Brace. 
Moore, H. E. (1966). The administration of public school personnel (2nd ed.). New York: Center for Applied Research in Education.

Mukhtar, A., \& Muslizah, Y. (2004, March 7). Sekolah Berkesan: Citra Watak Perwatakan Kedinamisme Kepengetuaan, National Seminar of Teacher Education, Jitra.

Northouse, P. G. (2004). Leadership theory and practice (3rd ed.) Thousand Oaks, CA: Sage Publications.

Okon, E. O., \& Zhizhi, A. S. (2016). Human Well-Being and Insurgencies in Nigeria: An Examination of Boko Haram Sect. International Journal of Economics, Business and Management Studies, 3(3), 143-153.

Okon, P. E. (2018). Comparative Analysis of Mass Media Coverage of the Fight Against Corruption in Nigeria by the Obasanjo and Buhari Administrations. International Journal of Emerging Trends in Social Sciences, 4(2), 47-57. https://doi.org/10.20448/2001.42.47.57

Okpechi, P. A., Denwigwe, C. P., Asuquo, P. N., Abuo, C., \& Unimna, F. U. (2018). Awareness and Utilization of e-Learning Resources by Trainee Counsellors of Counselling Education in Calabar, Nigeria. International Journal of Educational Technology and Learning, 3(2), 45-51. https://doi.org/10.20448/2003.32.45.51

Othman, A. H., \& Awang, A. (1993). Counselling in the Asia Pacific Region. Greenwood Press, Westport, U.S.A.

Othman, G. (2001). Sekolah berkesan dan program pembiakan sekolah di Malaysia. Past Issues of Educator Digest, $l(2)$.

Parham, \& Tinsley. (1986). Help seeking and problem perception among Asian. American Journal of Counselling Psychology, 33, 331-336. https://doi.org/10.1037//0022-0167.33.3.331

Patton, C. (2007, September). Smart Hiring. University Hiring, 10(9), 25-26.

Price, A. (2007). Human resource management in a business context (3rd ed.). Florence, KY: Thomson Learning.

Rosenbaum, J. E., \& Person, A. E. (2003). Beyond college for all: policies and practices to improved transitions in college and jobs. Professional School Counselling, 6(4), 252-260.

Salim, S. (1994b). Prospek masa depan perkhidmatan bimbingan dan kaunseling di Malaysia.

Santrok, J. W. (2001). Educational Psychology. New York: McGraw-Hill Company.

Saylor, J. H. (1999). TQM field manuals. New York: McGraw-Hill.

Schmidt, J. J. (2008). Comprehensive programs of responsive services for all students (5th ed.).

See, C. M., \& Ng, K.-M. (2010). Article Title?? by the American Counseling Association Journal of Counseling \& Development, 8818 , Winter.

Simpson, D. D. (2001). Modeling treatment process and outcomes. Addiction, 96(2), 207-211. https://doi.org/10.1046/j.1360-0443.2001.9622073.x

Sugrue, B. (2004, October). Making the case for learning. Training \& Development, 58(10), 75-77. Retrieved January $5, \quad 2008, \quad$ from http://encarta.msn.com/encnet/Departments/CareerTraining/?article=HumanResourcesCareers

Tan, S. N. (1989). A case study of students' reluctance in seeking counseling. Unpublished Masters Thesis, University Kebangsaan Malaysia. Thousand Oaks, CA: Sage Publications.

Thurow, L. C. (1996). The future of capitalism: How today's economic forces shape tomorrow's world. New York: William Morrow and Company, Inc.

Torrington, D., \& Hall, L. (1991). Personnel management: A new approach. New York: Prentice-Hall.

Truss, C., Gratton, L., Hope-Hailey, V., McGovern, P., \& Stiles, P. (1997, January). Soft and hard models of human resource management: A reappraisal. Journal of Management Studies, 34(1), 53-73. https://doi.org/10.1111/1467-6486.00042

Tyson, S. (1995). Strategic prospects for HRM. London: IPD.

Ulrich, D. (2007). Has HR finally arrived?. Workforce Management, 12(86), 51-53.

Webb, L. D., Montello, P. A., \& Norton, M. S. (1994). Human resources administration (2nd ed.). New York: Macmillan College Publishing. 